Available online at : http://journal.unj.ac.id/unj/index.php/gjik

Gladi Jurnal Ilmu Keolahragaan 07 (02) 2013, 780-799

Permalink/DOI: https://doi.org/10.21009/GJIK.072.04

\title{
HUBUNGAN ANTARA KOORDINASI MATA TANGAN, KEKUATAN PEGANGAN DAN KESEIMBANGAN DENGAN KETEPATAN MEMUKUL BOLA BISBOL PADA MAHASISWA FAKULTAS ILMU KEOLAHRAGAAN UNIVERSITAS NEGERI JAKARTA (2003)
}

\section{Taufik Rihatno ${ }^{1}$}

\begin{abstract}
Abstarct, The purpose of study is to find out the relationships between hand eye coordination, grip strenght with balance in baseball hitting accuracy. The research was conducted at faculty of sport and science, state university of Jakarta with 60 samples, which were selected by simple random sampling. The finding are as follows : (1) there is a positive correlation between hand eye coordination and baseball hitting accuracy, (2) there is a positive correlation between grip strenght and baseball hitting accuracy, (3) there is a positive correlation between balance and baseball hitting accuracy, (4) there is a positive correlation between hand eye coordination, grip strenght, and balance simultaneously with baseball hitting accuracy. It can be concluded that baseball hitting accuracy could be enhanced by increasing hand eye coordination, grip strength, and balance individually as well as simultaneously.
\end{abstract}

Keywords: hand eye coordination, grip strenght with balance, baseball

\footnotetext{
${ }^{1}$ Taufik Rihatno adalah Dosen Fakultas Ilmu Keolahragaan Unversitas Negeri Jakarta
} 


\section{PENDAHULUAN}

Prestasi cabang olahraga permainan bisbol di Indonesia pada saat ini cukup menggembirakan. Untuk di kawasan Asia, tim bisbol Indonesia satu divisi dengan negara Jepang, Taiwan, Cina, Korea, dan Filipina. Dengan masuknya tim bisbol Indonesia ke dalam satu kelompok dengan negara-negara tersebut, maka tim Indonesia bertemu dengan tim kelas dunia, seperti Jepang, Korea, dan Taiwan. Namun, apabila pembinaan dicabang olahraga permainan bisbol tidak diupayakan dengan intensif, maka prestasi yang sudah diperoleh bisa menurun.

Berdasarkan pengamatan peneliti, penguasaan teknik memukul bola bisbol terutama pada pemain pemula di tingkat mahasiswa, khususnya ketepatan memukul bola masih kurang baik. Hal ini terlihat dari hasil pukulannya, yaitu bola dengan mudah dikuasai oleh lawan, dan sasaran arah bolanya tidak mengarah ke posisi/tempat yang kosong dari penguasaan penjaga atau tidak mencapai pada target yang tepat. Oleh sebab itu, penguasaan teknik memukul bola harus dikuasai dengan baik oleh setiap pemain bisbol.

Suatu rangkaian gerak di dalam kegiatan olahraga menuntut optimalisasi komponen kondisi fisik yang terangkai secara harmonis dalam penguasaan koordinasi gerak keseluruhan. Adapun komponen kondisi fisik, yaitu terdiri dari koordinasi, kekuatan, keseimbangan, ketepatan, kecepatan, daya tahan, kelentukan,kelincahan, reaksi, dan daya ledak. Dari berbagai komponen kondisi fisik tersebut, peneliti berasumsi, bahwa koordinasi mata-tangan, kekuatan pegangan, dan keseimbangan merupakan komponen kondisi fisik yang paling mendukung dan memegang peranan penting dalam ketepatan memukul bola bisbol. Dengan demikian idealnya komponen ini perlu dilatih dan ditingkatan bagi seorang pemukul pemain bisbol.

Dalam permainan bisbol ketepatan memukul bola yang tepat dan terarah dapat dilakukan apabila seorang pemukul dapat mengkoordinasikan satu gerakan dengan gerakan yang lainnya. Oleh sebab itu, kemampuan seorang pemukul di dalam mengayunkan bat menuju ke sasaran bola datang agar hasil pukulannya tepat dibutuhkan keharmonisan gerakan antara koordinasi mata dan tangan. Dengan 
memiliki koordinasi mata dan tangan yang baik dapat memudahkan gerakan dengan tepat di dalam memukul bola. Demikian juga halnya dengan kemampuan kekuatan pegangan pada bat yang mempunyai peranan sangat penting di dalam upaya menghasilkan suatu pukulan yang tepat, sebab lemah di dalam memegang bat akan menyebabkan sulit untuk mengendalikan bat ketika terjadi benturan dengan bola. Selain itu, lemah dalam memegang bat pada saat terjadi benturan akan menyebabkan juga hasil pukulan tidak terarah, karena terjadi gesekan di antara bat dengan bola. Dengan demikian apabila memiliki kemampuan kekuatan pegangan yang baik, maka akan membantu seorang pemukul di dalam mengarahkan hasil pukulan bolanya yang tepat.

Agar tercapai ketepatan memukul bola dengan baik, selain dibutuhkan koordinasi mata tangan dan kekuatan pegangan, juga keseimbangan harus baik. Oleh karena, di dalam penguasan bola pada bat serta mempertahankan pandangan (kepala) supaya dapat bekerja dengan baik dibutuhkan konsentrasi total pada bola yang diikuti oleh keseimbangan tubuh. Mulai dari penyesuaian diri sebelum membuat ayunan, selama melangkah dan sesudah kontrol dengan bola. Rumusan Masalah Antara lain : Pertama, apakah terdapat hubungan antara koordinasi mata-tangan dan ketepatan memukul bola bisbol? Kedua, apakah terdapat hubungan antara kekuatan pegangan dan ketepatan memukul bola bisbol? Ketiga, apakah terdapat hubungan antara keseimbangan dan ketepatan memukul bola bisbol? Keempat, apakah terdapat hubungan secara bersama-sama antara koordinasi mata-tangan, kekuatan pegangan dan keseimbangan dengan ketepatan memukul bola bisbol?

\section{KAJIAN TEORETIK}

\section{Ketepatan Memukul Bola Bisbol}

Memukul bola pada permainan bisbol merupakan gerak dari keadaan diam, bergerak dan menghadapi obyek yang bergerak. Oleh sebab itu, membutuhkan ketepatan di dalam melakukannya. Pelaku harus dapat mengatur berapa besar kekuatan yang akan dikerahkan, mengkoordinasikan gerakan, dan menjaga 
keseimbangan tubuh agar dalam melakukan gerakan memukul bola dapat dengan tepat, baik itu menempatkan ketepatan pada perkenaan bat dengan bola maupun ketepatan di dalam mengarahkan bola ke arah sasaran yang dikehendaki.

Seorang pemain bisbol yang terampil dalam memukul bola, akan dapat melakukan pukulan bola dengan tepat dan terarah secara berulang-ulang kesuatu sasaran karena keterampilannya sudah tinggi (mahir), makin tinggi keterampilan pemukul akan makin mampu mengarahkan bola sesuai dengan kehendaknya. (Dadang Masnun, 1987 : 98). Memukul bola yang tepat dapat diperoleh dengan relaksasi (pengendoran), penghapusan ketegangan dan kekakuan konsentrasi total, keseimbangan, ayunan, perubahan tekanan pada waktu yang tepat, posisi yang cukup jauh dari plate sehingga dapat melangkah dengan pasti, bat yang sejajar, mata tertuju pada bola, kaki depan ke bawah dan pada waktu yang sama, kepala mundur dalam posisi “launching” atau meluncur, serta lengan terbentang penuh (Dell Bethel, 1987 : 131).

\section{Memilih Bat}

Untuk menentukan pilihan pada bat yang akan digunakan untuk memukul bola dalam permainan bisbol, seorang pemukul perlu memperhatikan beratnya bat, karena bat yang berat akan menyebabkan gerak memukul lambat, sedangkan bat yang ringan akan menyebabkan pukulan terlalu cepat untuk mengayun. Oleh sebab itu, pilihlah bat yang cocok untuk tangan dan penampilan fisik sendiri. Memilih bat adalah sangat penting untuk membantu mencapai kontrol yang sempurna (Lee P. Eilbracht, 1973 : 59).

\section{Pegangan (Grip)}

Cara memegang bat pada prinsipnya harus dipegang dengan dasar dari jarijemari bukan dengan telapak tangan maupun genggaman jempol. Bat yang dipegang dengan telapak tangan akan menghasilkan pukulan dan ayunan (swing) yang lambat (Julius Tetelepta, 1994 : 28). Empat jari merapat kecuali ibu jari terpisah. Genggaman harus kuat dan erat tetapi rileks sewajarnya supaya bat mudah digerakkan.

\section{Posisi berdiri pemukul (The stance)}


Posisi berdiri pemukul, yaitu berdiri pada kedua kaki yang dibuka selebar bahu, berat badan ditumpu oleh kedua kaki (titik berat badan jatuh ditengah-tengah bidang tumpu). Badan sedikit condong kedepan dan lutut sedikit dibengkokkan. Lutut dan panggul harus rileks. Bat dipegang erat oleh kedua tangan yang terletak di depan dari badan dan kedua tangan berada di atas kaki belakang. Posisi bat rebah ke belakang dengan kedudukan kurang lebih antara horisontal dan vertikal. Bahu muka dan bahu belakang sejajar. Usahakan jangan sampai bahu muka lebih tinggi dari pada bahu belakang. Kepala selalu dalam posisi tegak dengan dagu terletak diatas bahu depan masuk ke arah depan sedikit, kedua mata diarahkan ke bola. Untuk posisi tubuh di tempat pemukul (batter box) di atur kira-kira ditengah kotak pembatas tersebut, dengan prediksi bola yang dilempar ke arah manapun masih dapat diraih.

\section{Ayunan (Swing)}

Pada pase gerakan ayunan ini dilakukan dengan menggerakan bat ke arah bola. Pemukul harus pandai mengambil “timing” yang tepat antara mengayunkan bat dengan datangnya bola sehingga terjadi kontak antara bat dan bola, oleh sebab itu ada beberapa hal yang perlu diperhatikan dalam gerakan tersebut, yaitu melangkah, perkenaan bola, dan gerak lanjutan.

\section{Melangkah}

Sebelum gerakan melangkah dilakukan terlebih dahulu batter melakukan gerakan menarik ke belakang (back swing) dari sikap normal memegang bat. Posisi kepala tetap dipertahankan seperti semula, pandangan mata sudah terkonsentrasikan menanti bola datang. Lakukan langkah (striding) pada kaki depan sesuai dengan jangkauan yang enak.

\section{Perkenaan Bola}

Setelah langkah kaki depan berakhir (mendarat ditanah) dan bola sudah dilempar oleh pitcher, saat itu pula lengan mengayunkan bat dengan gerakan cepat, terutama dengan menggunakan kekuatan pergelangan tangan yang diikuti berputarnya bahu, pinggang dan kaki hingga terjadi perkenaan (bertemunya bat dan bola). Saat bertemunya bat dan bola, posisi yang benar adalah saat bat horizontal 
didepan pemukul, tangan kiri lurus (untuk pemukul kanan) dan “timing” yang pas atau waktunya tepat saat perkenaan (tidak boleh terlalu lambat tidak boleh terlalu cepat).

\section{Gerak lanjutan}

Ketika bat kontak dengan bola gerakan lengan tidak berakhir pada saat itu, lengan bergerak mengikuti arah gerakan, pergelangan tangan terus berputar dan pergelangan tangan sebelah kanan akan berakhir disebelah atas pergelangan tangan kiri sehingga lengan menyilang pada tubuh dan punggung berputar penuh. Gerak lanjutan merupakan gerak akhir dari melakukan pukulan ayunan atau gerakan sesudah perkenaan bola dan terjadi secara wajar. Gerakan ini dapat bermanfaat untuk mengurangi bahaya dari gerakan persendian.

Dengan demikian, maka ketepatan memukul bola adalah kemampuan seseorang dalam mengarahkan ayunan bat menuju pusat berat bola datang dengan tepat hingga terjadi benturan yang kemudian menghasilkan lajunya bola melayang ke arah tertentu sesuai dengan daerah sasaran yang diinginkan di lapangan permainan bisbol.

\section{Koordinasi Mata Tangan}

Koordinasi adalah kemampuan untuk menggunakan pancaindera bersamasama dengan bagian-bagian tubuh tertentu didalam melakukan kegiatan motorik dengan mulus (harmonis) dan ketepatan yang tinggi (Suhantoro, 1999 : 6). Kemampuan mengkoordinasikan termasuk aktivitas yang terdiri dari dua atau lebih kemampuan dan pola gerak, seperti mata-tangan membutuhkan kemampuan pengamatan dan bentuk pergerakan. Koordinasi mata-tangan menunjukkan kepada kemampuan mempelajari untuk menyeleksi objek dan sekelilingnya serta untuk mengkoordinasikan objek pandangan dengan manipulasi gerakan. Koordinasi matatangan kegiatannya membutuhkan ketepatan pandangan dan kontrol pergerakan (Anita J. Harrow, 1972 : 67). 
Rangkaian gerakan di dalam memukul bola pada permainan bisbol, memerlukan permadukan dua atau lebih kemampuan dan pola gerakan yang saling berkait guna menghasilkan pukulan yang sempurna. Seorang pemukul harus mampu mengkoordinasikan antara mata dan tangan karena terciptanya kontak/benturan antara bat dan bola melalui proses pengamatan mata yang bekerjasama dengan tangan sehingga tugas gerak dapat dilakukan dengan mudah. Seorang pemukul dapat melakukan timing yang tepat, pada saat perkenaan bat dengan bola, Dengan terjadinya benturan kedua benda tersebut diposisi yang tepat sehingga memungkinkan tidak terjadinya gesekan yang berarti antara bat dan bola ataupun bola tidak kena pukul akan terhindari.

Dengan demikian, maka koordinasi mata-tangan adalah kemampuan untuk melakukan pengontrolan terhadap gerakan otot dari satu pola gerakan ke pola gerakan berikutnya dengan tepat melalui keterpaduan antara mata dan tangan secara harmonis.

\section{Kekuatan Pegangan}

Kekuatan salah satu dari komponen kondisi fisik, keberadaannya tidak hanya diperlukan untuk cabang olahraga yang dominan pada unsur kekuatan, namun diperlukan juga oleh cabang olahraga lain yang lebih memerlukan kelincahan, kecepatan, kelentukan, keseimbangan dan koordinasi (Harsono, 1988 : 54). Begitu pula, memukul bola dengan alat pemukul terhadap bola lemparan pitcher adalah hal yang sulit dilakukan karena memerlukan ketelitian, koordinasi dan kekuatan (Parno, 1992 : 85). Komponen kekuatan merupakan salah satu komponen diantara komponen-komponen biomotorik lainnya. Komponen biomotorik terdiri dari kekuatan, daya tahan, dan koordinasi (Peter J. Thompson, 1991 : 5.11) Komponenkomponen tersebut saling terkait satu sama lainnya sehingga membentuk satu siklus rangkaian gerak.

Berdasarkan uraian di atas terlihat, bahwa memegang bat di dalam melakukan gerakan memukul bola bisbol sangatlah mendasar untuk melakukan suatu pukulan yang baik. Kemampuan kekuatan memegang bat dari posisi bat diacungkan sampai bat diayunkan, benar-benar dapat dipertahankan dan dijaga jangan sampai bat 
tersebut terlepas. Apalagi ketika terjadi pada saat perkenaan/kontak antara bat dan bola, kekuatan pada jari jemari tangan memegang bat seoptimalkan mungkin untuk dikerahkan memegang bat dengan kuat, namun tidak mengganggu gerakan selanjutnya

Dengan demikian, maka kekuatan pegangan pada penelitian ini adalah kemampuan dari otot atau sekelompok otot pada jari jemari tangan dalam mengatasi tahanan beban secara maksimal.

\section{Keseimbangan}

Keseimbangan merupakan salah satu komponen kondisi fisik yang sangat diperlukan bagi manusia, baik sebagai olahragawan maupun seseorang dalam melakukan aktifitas sehari-hari. Kegiatan manusia dalam kehidupannya selalu menjaga posisi tubuhnya, baik itu dalam keadaan diam (statis), maupun bergerak diposisi yang seimbang (dinamis). Brian J. Sharkey (1986 : 44) menjelaskan bahwa keseimbangan yang dinamis adalah kemampuan memelihara keseimbangan selama kegiatan bergerak, sedangkan keseimbangan statis adalah kemampuan memelihara keseimbangan dalam posisi tak berubah. Keseimbangan juga berhubungan dengan menjaga keseimbangan pada saat bergerak (David C. Naimen, 1990 : 30). Faktor yang mempengaruhi keseimbangan dalam aktifitas gerak antara lain : (1) Luas bidang tumpuan, (2) Posisi pusat gravitasi, (3) Massa seseorang (Bloomfield J, Ackland, 1994 : 262).

Dengan demikian, keseimbangan adalah kemampuan untuk mempertahankan dan menjaga posisi tubuh dari saat akan melakukan gerakan dan selama gerakan itu berlangsung, keadaan tubuh tetap terkontrol.

\section{KERANGKA BERFIKIR}

\section{Hubungan antara Koordinasi Mata-Tangan dan Ketepatan Memukul Bola}

\section{Bisbol}

Pada pelaksanaan memukul bola dalam permainan bisbol meliputi ayunan bat yang harus tepat perkenaannya dengan bola dan mengarahkannya ke arah lapangan 
yang di inginkan. Pemantauan secara visual oleh kedua mata dalam memukul bola sangat dibutuhkan untuk memperhatikan jalannya bola dan posisi bola yang akan diprediksi untuk dipukul. Mata melihat bola kemudian menginterpretasikan saat itu juga kapan melakukan gerakan mengayunkan bat tersebut. Mata yang sebagai alat pengantar gambar ke otak, lalu otak yang memberikan interpretasi terhadap apa yang dituju oleh mata, maksudnya mata bersama otak dan otot untuk mengkoordinasikannya. Mata yang mengirimkan sinyal ke otak. Otak dengan segera mengirimkan sinyal ke otot.

Otak dengan segera mengirimkan sinyal lagi kembali ke otot agar otot lengan menggerakkan atau mengayunkan bat dengan cepat, tepat dan harmonis. Seiring dengan gerakan tersebut ketika terjadi benturan antara bat dan bola maka dengan sangat cepat tanpa dipikirkan terlebih dahulu, simpul dari tangan berjalan ke otak untuk menyatakan kalau bat yang dipegang itu jangan sampai terlepas akibat benturan dan bat harus dipegang dengan kuat, sehingga bola yang dipukul dapat memberikan hasil kecepatan lajunya bola kearah tertentu sesuai dengan tujuan menempatkan bola yang dikehendaki. Dengan demikian, diduga terdapat hubungan positif antara koordinasi mata-tangan dan ketepatan memukul bola bisbol.

\section{Hubungan Antara Kekuatan Pegangan dan Ketepatan Memukul Bola}

\section{Bisbol.}

Memegang bat pada gerakan memukul bola yang efisien, pemukul harus menghasilkan tenaga maksimum. Ketidak efisienan dalam mengeluarkan tenaga yang memadai dari pegangan ke bat akan menghasilkan pukulan bola yang lemah dan tidak terarah, oleh sebab itu salah satu faktor yang paling mendasar untuk mendapatkan hasil pukulan yang kencang dan terarah masalah kekuatan pegangan pada bat harus diperhatikan. Apabila pegangan pada bat tidak kuat, maka kemungkinan akan kehilangan kekuatan karena tenaga dari tubuh tidak sepenuhnya dapat disalurkan ke bat dan dapat menyulitkan untuk mengarahkan hasil pukulan bola yang tepat pada sasaran diinginkan 
Oleh karena itu, apabila seorang pemain bisbol dapat melakukan pegangan dengan kuat pada bat, terutama pada saat perkenaan antara bat dan bola, maka kemungkinkan untuk melakukan pukulan terhadap bola akan lebih effektif karena seorang pemukul dapat menguasai pegangan pada bat, sehingga untuk mengarahkan bagian pusat pukul bat tepat menuju pusat berat bola terkendali. Dengan demikian, diduga terdapat hubungan yang positif antara kekuatan pegangan dan ketepatan memukul bola bisbol.

\section{Hubungan Antara Keseimbangan dan Ketepatan Memukul Bola Bisbol}

Pinggul dan bahu yang sejajar dalam membuat gerakan ayunan memukul untuk mempertahankan juga keseimbangan, karena penjajaran (pinggul dan bahu) yang tidak seimbang, ada kemungkinan seorang pemukul dalam memanfaatkan bidang ayunan menjadi tidak terkontrol. Selain menjaga bahu tetap rata akan membantu pemukul menjaga posisi tangan berada di daerah zona lemparan ( strike zone). Begitu pula tentang keberadaan kepala dalam mempertahankan keseimbangan. Kepala ditahan hampir tidak bergerak ketika mengayunkan bat, pandangan mata tertuju ke depan mengamati atau melihat bola yang datang. Dengan demikian semakin tinggi tingkat kestabilan seorang pemukul dalam bergerak, maka semakin besar kemampuannya untuk mempertahankan keseimbangan pada saat bergerak dan akan semakin tepat kemampuannya dalam merubah posisi tubuh, sehingga bisa merespon dan mengontrol tubuhnya untuk melakukan gerakan memukul bola dengan tepat. Dengan demikian, diduga terdapat hubungan positip antara keseimbangan dan ketepatan memukul bola bisbol.

\section{Hubungan Antara Koordinasi Mata-tangan, Kekuatan Pegangan dan Keseimbangan Dengan Ketepatan Memukul Bola Bisbol}

Di dalam ketepatan memukul bola komponen koordinasi mata tangan, kekuatan pegangan dan keseimbangan adalah komponen fisik yang sangat dibutuhkan karena sebagai komponen pendukung. Dengan memiliki pengkoordinasian mata tangan yang baik dalam mengantisipasi bola datang dan mempunyai kekuatan 
pegangan pada bat yang mampu menerima beban kerja serta memiliki kemampuan mempertahankan keseimbangan dalam melakukan gerakan memukul bola, maka seorang pemukul pemain bisbol tersebut akan dapat dengan mudah melakukan ketepatan di dalam memukul bola sehingga akan menghasilkan pukulan bola yang kencang dan terarah. Dengan demikian,diduga terdapat hubungan yang positif antara koordinasi mata-tangan, kekuatan pegangan dan keseimbangan secara bersama-sama dengan ketepatan memukul bola bisbol.

\section{Hipotesis Penelitian}

Berdasarkan kajian teoretis dan kerangka berpikir maka hipotesis penelitian dapat dirumuskan sebagai berikut :

1. Terdapat hubungan positif antara koordinasi mata tangan dan ketepatan memukul bola bisbol.

2. Terdapat hubungan positif antara kekuatan pegangan dan ketepatan memukul bola bisbol.

3. Terdapat hubungan positif antara keseimbangan dan ketepatan memukul bola bisbol.

4. Terdapat hubungan positif antara koordinasi mata-tangan, kekuatan pegangan dan keseimbangan secara bersama-sama dengan ketepatan memukul bola bisbol.

\section{METODOLOGI PENELITIAN}

Penelitian ini bertujuan untuk mengetahui hubungan koordinasi matatangan, kekuatan pegangan, dan keseimbangan baik secara sendiri-sendiri maupun secara bersama-sama dengan ketepatan memukul bola bisbol.

Penelitian ini dilaksanakan di Fakultas Ilmu Keolahragaan Universitas Negeri Jakarta. Waktu pelaksanaan di mulai dari bulan Februari sampai bulan Mei 2003. Penelitian ini menggunakan metode survei dengan analisis regresi sederhana dan ganda, korelasi sederhana dan ganda, serta korelasi parsial. 
Penelitian survei yang melibatkan empat variabel, yaitu: koordinasi matatangan, kekuatan pegangan, dan keseimbangan sebagai variabel bebas, sedangkan ketepatan memukul bola bisbol merupakan veriabel terikat. Untuk lebih menjelaskan tentang variabel yang diteliti dapat dilihat konstelasi permasalahan sebagai berikut:

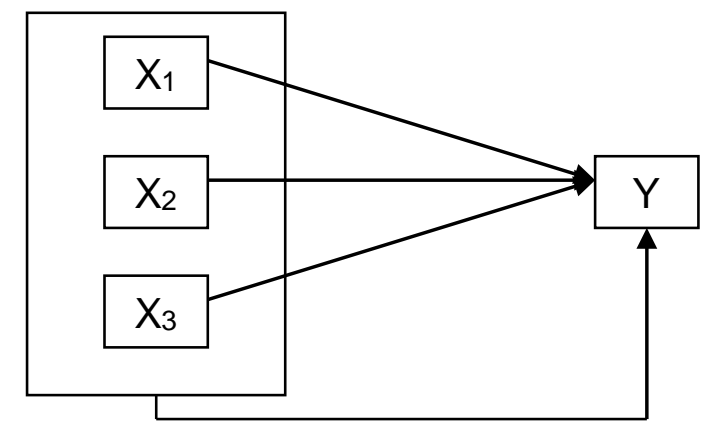

\section{Gambar 1. Konstelasi Hubungan Antara Variabel}

\section{Keterangan:}

Y : Ketepatan Memukul Bola Bisbol

$\mathrm{X}_{1} \quad$ : Koordinasi Mata-Tangan

$\mathrm{X}_{2} \quad$ : Kekuatan Pegangan

$\mathrm{X}_{3} \quad$ : Keseimbangan

Populasi penelitian ini adalah mahasiswa putra yang telah selesai (lulus) mengikuti mata kuliah permainan sofbol/bisbol di Fakultas Ilmu Keolahragaan. Teknik pengambilan sample dilakukan dengan menggunakan teknik acak sederhana,melalui undian dan didapat sampel 60 orang. Pengumpulan data dilakukan dengan menggunakan: (1) tes ketepatan memukul bola bisbol (Instrumen yang dikembangkan oleh peneliti), (2) tes koordinasi mata tangan dengan mempergunakan eye hand coordination (instrumen baku), (3) tes kekuatan pegangan dengan mempergunakan hand grip dynamometer (instrument baku), (4) tes keseimbangan dengan mempergunakan bass test of dynamic balance (instrumen baku). 


\section{HASIL PENELITIAN}

Pengujian Persyaratan Analisis

Pengujian persyaratan analisis yang harus dipenuhi sebelum melakukan analisis regresi linear sederhana dan ganda adalah melakukan pengujian persyaratan analisis, yaitu pengujian normalitas, pengujian homogenitas varians, dan pengujian linearitas.

Tabel 1. Rangkuman Hasil Uji Normalitas

\begin{tabular}{|l|l|l|l|l|}
\hline No & Galat Taksiran & L $_{\text {hitung }}$ & L tabel & Kesimpulan \\
\hline 1 & Regresi Y atas $X_{1}$ & 0,111 & 0,114 & Normal \\
2 & Regresi Y atas $X_{2}$ & 0,084 & 0,114 & Normal \\
3 & Regresi Y atas $X_{3}$ & 0,075 & 0,114 & Normal \\
\hline
\end{tabular}

Tabel 2. Rangkuman Hasil Uji Homogenitas

\begin{tabular}{|l|l|l|l|l|}
\hline No & Varian $\mathrm{Y}$ atas $\mathrm{X}_{\mathrm{i}}$ & $\chi_{\text {hitung }}^{2}$ & $\chi_{\text {tabel }}^{2}$ & Kesimpulan \\
\hline 1 & Regresi $\mathrm{Y}$ atas $\mathrm{X}_{1}$ & 12,116 & 67,5 & Homogen \\
2 & Regresi $\mathrm{Y}$ atas $\mathrm{X}_{2}$ & 11,984 & 36,4 & Homogen \\
3 & Regresi $\mathrm{Y}$ atas $\mathrm{X}_{3}$ & 14,724 & 36,4 & Homogen \\
\hline
\end{tabular}

\section{Pengujian Hipotesis}

\section{Hubungan Antara Koordinasi Mata Tangan dan Ketepatan Memukul Bola Bisbol}

Hipotesis pertama yang diajukan adalah terdapat hubungan positif antara koordinasi mata tangan dan ketepatan memukul bola bisbol. Hal ini, dinyatakan dalam persamaan regresi untuk hubungan kedua veriabel di atas adalah $\hat{Y}=7,860+$ $0,843 \mathrm{X}_{1}$. 
Berdasarkan hasil uji signifikansi dan linearitas persamaan regresi seperti yang tercantum pada Tabel 3, dapat disimpulkan, bahwa persamaan regresi $\hat{Y}=$ $7,860+0,843 \mathrm{X}_{1}$ adalah sangat signifikan dan linear. Selanjutnya dari persamaan regresi tersebut dapat diinterpretasikan, bahwa apabila koordinasi mata-tangan ditingkatkan satu skor, maka kecenderungan ketepatan memukul bola bisbol meningkat sebesar 0,843 skor pada konstanta 7,860.

Kekuatan hubungan koordinasi mata tangan $\left(\mathrm{X}_{1}\right)$ dengan Ketepatan memukul bola bisbol (Y) menghasilkan koefisien korelasi ( $r_{\mathrm{y} 1}$ ) sebesar 0,84. Uji signifikansi koefisien korelasi dengan uji $\mathrm{t}$ diperoleh $\mathrm{t}_{\text {hitung }}=11,93$ lebih besar dari $\mathrm{t}_{\text {tabel }}=2,39$, dapat disimpulkan bahwa koefisien korelasi antara koordinasi mata-tangan dan ketepatan memukul bola bisbol sangat signifikan. Apabila dilakukan pengontrolan terhadap variabel prediktor lainnya, yakni kekuatan pegangan $\left(\mathrm{X}_{2}\right)$ maka diperoleh koefisien korelasi parsial antara koordinasi mata tangan $\left(\mathrm{X}_{1}\right)$ dan ketepatan memukul bola bisbol $(\mathrm{Y})$ sebesar 0,57 , bila dikontrol keseimbangan $\left(\mathrm{X}_{3}\right)$ menghasilkan koefisien korelasi parsial sebesar 0,79, jika dikontrol kekuatan pegangan $\left(\mathrm{X}_{2}\right)$ dan keseimbangan $\left(\mathrm{X}_{3}\right)$, maka koefisien korelasinya sebesar 0,61. Analisis ini dilanjutkan dengan "uji t” untuk mengetahui signifikansi hubungan antara koordinasi mata tangan dengan ketepatan memukul bola bisbol. Untuk lebih jelasnya hasil perhitungan koefisien korelasi sederhana dan parsial tersebut disajikan pada Tabel 4.

Tabel 3. Hasil perhitungan Koefisien Korelasi sederhana dan Parsial Antara Koordinasi Mata Tangan $\left(\mathrm{X}_{1}\right)$ dan Ketepatan Memukul Bola Bisbol (Y) bila Kekuatan Pegangan $\left(\mathrm{X}_{2}\right)$ dan Keseimbangan $\left(\mathrm{X}_{3}\right)$ dikontrol.

\begin{tabular}{|c|c|c|c|c|c|c|}
\hline & \multirow{2}{*}{$\begin{array}{l}\text { Sampel } \\
\text { (n) }\end{array}$} & \multirow[t]{2}{*}{$\mathrm{dk}$} & \multirow{2}{*}{$\begin{array}{l}\text { Koefisien } \\
\text { Korelasi }\end{array}$} & \multirow[t]{2}{*}{$\mathrm{t}_{\text {hitung }}$} & \multicolumn{2}{|l|}{$t_{\text {tabel }}$} \\
\hline & & & & & $\alpha 0,05$ & $\alpha 0,01$ \\
\hline $\begin{array}{l}\text { Korelasi } \\
\text { Sederhana }\left(\mathrm{r}_{\mathrm{yi}}\right)\end{array}$ & 60 & 58 & 0,84 & $11,93 * *$ & 1,67 & 2,39 \\
\hline $\begin{array}{l}\text { Korelasi Parsial } \\
\left(\mathrm{r}_{\mathrm{y} 1.2}\right)\end{array}$ & 60 & 57 & 0,57 & $5,27 * *$ & 1,67 & 2,39 \\
\hline
\end{tabular}




\begin{tabular}{|l|l|l|l|l|l|l|}
\hline$\left(r_{\mathrm{y} 1.3}\right)$ & 60 & 57 & 0,79 & $9,61 * *$ & 1,67 & 2,39 \\
$\left(r_{\mathrm{y} 1.23}\right)$ & 60 & 56 & 0,61 & $5,77^{* *}$ & 1,67 & 2,39 \\
\hline
\end{tabular}

Keterangan:

**Sangat Signifikan

\section{Hubungan Antara Kekuatan Pegangan dan Ketepatan Memukul Bola Bisbol}

Hubungan antara kekuatan pegangan ( $\left.\mathrm{X}_{2}\right)$ dan ketepatan memukul bola bisbol ( $\mathrm{Y}$ ), ditunjukan dengan persamaan regresi $\hat{Y}=9,012+0,819 \mathrm{X}_{2}$.

Berdasarkan hasil pengujian signifikansi dan linearitas pada Tabel 5 bahwa regresi $\hat{Y}=9,012+0,819 \mathrm{X}_{2}$. adalah sangat signifikan dan linear. Model regresi tersebut mengandung arti bahwa ketepatan memukul bola bisbol akan meningkat sebesar 0,819 skor, jika kekuatan pegangan ditingkatkan satu unit pada konstanta 9,012 .

Kekuatan hubungan antara variabel Kekuatan pegangan $\left(\mathrm{X}_{2}\right)$ dan Ketepatan memukul bola bisbol (Y) ditunjukkan oleh koefisien korelasi ( $\mathrm{r}_{\mathrm{y2}}$ ) sebesar 0,82. Uji signifikansi koefisien korelasi dengan uji $\mathrm{t}$ diperoleh $\mathrm{t}$ hitung $=10,77$ lebih besar dari $\mathrm{t}$ tabel $=2,39$. Dengan demikian dapat disimpulkan bahwa koefisien korelasi antara kekuatan pegangan dan ketepatan memukul bola bisbol sangat signifikan. Apabila dilakukan pengontrolan terhadap variabel prediktor lainnya, yakni koordinasi mata tangan $\left(\mathrm{X}_{1}\right)$ maka diperoleh koefisien korelasi parsial antara kekuatan pegangan $\left(\mathrm{X}_{2}\right)$ dan ketepatan memukul bola bisbol (Y) sebesar 0,47, apabila dikontrol keseimbangan $\left(\mathrm{X}_{3}\right)$ menghasilkan koefisien korelasi parsial sebesar 0,67, jika dikontrol koordinasi mata tangan $\left(\mathrm{X}_{1}\right)$ dan keseimbangan $\left(\mathrm{X}_{3}\right)$, maka koefisien korelasinya sebesar 0,28. Analisis ini dilanjutkan dengan "uji t” untuk mengetahui signifikansi hubungan antara kekuatan pegangnan dan ketepatan memukul bola bisbol. Untuk lebih jelasnya hasil perhitungan koefisien korelasi sederhana dan parsial tersebut disajikan pada Tabel 6. 
Tabel 5. Hasil perhitungan Koefisien Korelasi sederhana dan Parsial Antara Kekuatan Pegangan $\left(\mathrm{X}_{2}\right)$ dan Ketepatan Memukul Bola Bisbol (Y) bila Koordinasi mata tangan $\left(\mathrm{X}_{1}\right)$ dan Keseimbangan $\left(\mathrm{X}_{3}\right)$ dikontrol.

\begin{tabular}{|c|c|c|c|c|c|c|}
\hline & \multirow{2}{*}{$\begin{array}{l}\text { Sampel } \\
\text { (n) }\end{array}$} & \multirow[t]{2}{*}{$\mathrm{dk}$} & \multirow{2}{*}{$\begin{array}{l}\text { Koefisien } \\
\text { Korelasi }\end{array}$} & \multirow[t]{2}{*}{$\mathrm{t}_{\text {hitung }}$} & \multicolumn{2}{|l|}{$t_{\text {tabel }}$} \\
\hline & & & & & $\alpha 0,05$ & $\alpha 0,01$ \\
\hline $\begin{array}{l}\text { Korelasi } \\
\text { Sederhana }\left(\mathrm{r}_{\mathrm{yi}}\right)\end{array}$ & 60 & 58 & 0,8888 & $10,77^{* *}$ & 1,67 & 2,39 \\
\hline $\begin{array}{l}\text { Korelasi Parsial } \\
\left(\mathrm{r}_{\mathrm{y} .2 .1}\right) \\
\left(\mathrm{r}_{\mathrm{y} 2.3}\right) \\
\left(\mathrm{r}_{\mathrm{y} .2 .1 .3}\right)\end{array}$ & $\begin{array}{l}60 \\
60 \\
60\end{array}$ & $\begin{array}{l}57 \\
57 \\
56\end{array}$ & $\begin{array}{l}0,47 \\
0,67 \\
0,28\end{array}$ & $\begin{array}{l}4,55^{* *} \\
9,20^{* *} \\
2,27^{*}\end{array}$ & $\begin{array}{l}1,67 \\
1,67 \\
1,67\end{array}$ & $\begin{array}{l}2,39 \\
2,39 \\
2,39\end{array}$ \\
\hline
\end{tabular}

Keterangan:

**Sangat Signifikan

*Signifikan

\section{Hubungan Antara Keseimbangan dan Ketepatan Memukul Bola Bisbol}

Hubungan antara keseimbangan ( $\mathrm{X}_{3}$ ) dan ketepatan memukul bola bisbol (Y) yang ditunjukkan dalam persamaan regresi $\hat{Y}=14,960+0,701 X_{3}$.

Hasil pengujian signifikansi dan linearitas pada Tabel 7 bahwa persamaan regresi $\hat{Y}=14,960+0,701 \mathrm{X}_{3}$. adalah sangat signifikan dan linear. Model regresi tersebut mengandung arti bahwa Ketepatan memukul bola bisbol akan meningkatan sebesar 0,701 skor, Jika keseimbangan ditingkatkan satu unit pada konstanta 14,960.

Kekuatan hubungan antara variabel Keseimbangan $\left(\mathrm{X}_{3}\right)$ dan Ketepatan memukul bola bisbol $(\mathrm{Y})$ ditunjukkan oleh koefisien korelasi ( $\left.\mathrm{r}_{\mathrm{y} 3}\right)$ sebesar 0,70. Hasil uji signifikan koefisien korelasi dengan uji t, diperoleh $t$ hitung $=$ 7,48 lebih besar dari $\mathrm{t}$ tabel $=2,39$. Dengan demikian dapat disimpulkan bahwa koefisien korelasi antara keseimbangan dan ketepatan memukul bola bisbol sangat signifikan. Apabila dilakukan pengontrolan terhadap variabel prediktor lainnya, yakni koordinasi mata tangan $\left(\mathrm{X}_{1}\right)$ maka diperoleh koefisien korelasi parsial antara keseimbangan $\left(\mathrm{X}_{3}\right)$ dan 
ketepatan memukul bola bisbol (Y) sebesar 0,58, bila dikontrol kekuatan pegangan $\left(\mathrm{X}_{2}\right)$ menghasilkan koefisien korelasi parsial sebesar 0,39, jika dikontrol koordinasi mata tangan $\left(\mathrm{X}_{1}\right)$ dan kekuatan pegangan $\left(\mathrm{X}_{2}\right)$, maka koefisien korelasinya sebesar 0,46. Analisis ini dilanjutkan dengan “uji t” untuk mengetahui signifikansi hubungan antara keseimbangan dan ketepatan memukul bola bisbol. Untuk lebih jelasnya hasil perhitungan koefisien korelasi sederhana dan parsial tersebut disajikan pada Tabel 8.

Tabel 6. Hasil Perhitungan Koefisien Korelasi Sederhana dan Parsial Antara keseimbangan $\left(\mathrm{X}_{3}\right)$ dan Ketepatan Memukul Bola Bisbol (Y), bila Koordinasi Mata Tangan $\left(\mathrm{X}_{1}\right)$ dan Kekuatan Pegangan $\left(\mathrm{X}_{2}\right)$ Dikontrol.

\begin{tabular}{|c|c|c|c|c|c|c|}
\hline & Sampel & $\mathrm{dk}$ & Koefisien & $t_{\text {hitung }}$ & $\mathrm{t}_{\text {tabel }}$ & \\
\hline & (n) & & Korelasi & & $\alpha 0,05$ & $\alpha 0,01$ \\
\hline $\begin{array}{l}\text { Korelasi } \\
\text { Sederhana }\left(\mathrm{r}_{\mathrm{yi}}\right)\end{array}$ & 60 & 58 & 0,70 & $7,48 * *$ & 1,67 & 2,39 \\
\hline $\begin{array}{l}\text { Korelasi Parsial } \\
\left(\mathrm{r}_{\mathrm{y} 3.1}\right) \\
\left(\mathrm{r}_{\mathrm{y} 3.2}\right) \\
\left(\mathrm{r}_{\mathrm{y} 3.1 .2}\right)\end{array}$ & $\begin{array}{l}60 \\
60 \\
60\end{array}$ & $\begin{array}{l}57 \\
57 \\
56\end{array}$ & $\begin{array}{l}0,58 \\
0,39 \\
0,46\end{array}$ & $\begin{array}{l}6,64 * * \\
3,46 * * \\
4,35 * *\end{array}$ & $\begin{array}{l}1,67 \\
1,67 \\
1,67\end{array}$ & $\begin{array}{l}2,39 \\
2,39 \\
2,39\end{array}$ \\
\hline
\end{tabular}

Keterangan:

**Sangat Signifikan

Hubungan Antara Koordinasi Mata Tangan, Kekuatan Pegangan dan Keseimbangan dengan Ketepatan Memukul Bola Bisbol

Hubungan antara koordinasi mata tangan $\left(\mathrm{X}_{1}\right)$, kekuatan pegangan $\left(\mathrm{X}_{2}\right)$, dan keseimbangan $\left(\mathrm{X}_{3}\right)$ secara bersama-sama dengan ketepatan memukul bola bisbol (Y). Hal ini dinyatakan dalam persamaan regresi ganda $\hat{Y}=-1,638+0,519 X_{1}+0,224 X_{2}+$ $0_{2} 2_{3}$. Model persamaan tersebut mengandung arti bahwa apabila secara bersama-sama koordinasi mata-tangan, kekuatan pegangan, dan keseimbangan ditingkatkan sebesar satu skor, maka akan terjadi kecenderungan peningkatan 
ketepatan memukul bola bisbol sebesar 0,519 +0,224 + 0,289 skor dengan konstanta sebesar $-1,638$.

Hasil perhitungan untuk kekuatan hubungan antara koordinasi mata tangan $\left(\mathrm{X}_{1}\right)$, kekuatan pegangan $\left(\mathrm{X}_{2}\right)$, dan keseimbangan $\left(\mathrm{X}_{3}\right)$ dengan ketepatan memukul bola bisbol, diperoleh nilai koefisien korelasi ganda $\mathrm{R}_{\mathrm{y}} 123$ sebesar 0,91.Selanjutnya untuk mengetahui signifikansi koefisien korelasi ganda, maka dilakukan pengujian terhadap hipotesis dengan mempergunakan uji "F". Berdasarkan hasil analisis diperoleh $\mathrm{F}_{\text {hitung }}=86,69$ lebih besar bila dibandingkan dengan $\mathrm{F}_{\text {tabel }}=4,16$. Hal ini berarti, bahwa koordinasi mata tangan, kekuatan pegangan, dan keseimbangan dengan ketepatan memukul bola bisbol memiliki hubungan yang sangat signifikan. Untuk lebih jelasnya dapat dilihat pada Tabel 10 berikut ini.

Tabel 7. Hasil Perhitungan Koefisien Korelasi Ganda.

\begin{tabular}{|l|l|l|c|}
\hline Koefisien Korelasi & F Fitung & \multicolumn{2}{|l|}{$F_{\text {tabel }}$} \\
\cline { 3 - 4 } & & $\alpha 0,05$ & $\alpha 0,01$ \\
\hline 0,91 & $86,69 * *$ & 2,78 & 4,44 \\
\hline
\end{tabular}

Keterangan:

** Koefisien korelasi ganda sangat signifikan $\left(\mathrm{F}_{\text {hitung }}=86,69>\mathrm{F}_{\text {tabel }}=4,16\right)$

\section{KESIMPULAN}

Sesuai dengan temuan penelitian yang telah dikemukakan, maka kesimpulan dalam penelitian ini adalah ketepatan memukul bola bisbol dapat ditingkatkan melalui peningkatan koordinasi mata tangan, kekuatan pegangan, dan keseimbangan, baik secara sendiri-sendiri maupun secara bersama-sama.

\section{SARAN}

Dengan ditemukannya bahwa ketepatan memukul bola bisbol dapat ditingkatkan melalui koordinasi mata tangan, kekuatan pegangan, dan keseimbangan 
dari hasil penelitian ini, maka ada beberapa yang perlu disarankan antara lain dapat dikemukakan sebagai berikut:

1. Dalam upaya meningkatkan kemampuan ketepatan memukul bola dalam permainan bisbol, maka para pelatih, pembina dan tenaga pengajar olahraga khususnya di lembaga Fakultas Ilmu Keolahragaan Universitas Negeri Jakarta perlu memperhatikan mahasiswanya, di dalam latihan memukul bola, seperti komponen kondisi fisik koordinasi mata tangan, kekuatan pegangan dan keseimbangan.

2. Dalam memilih atau menjalankan talent scouting untuk tim/pemain bisbol Fakultas Ilmu Keolahragaan Universitas Negeri Jakarta , maka koordinasi mata tangan, kekuatan pegangan dan keseimbangan dapat dijadikan sebagai indikator untuk memilih pemain bisbol.

3. Untuk pembinaan pemain bisbol Fakultas Ilmu Keolaharagaan Universitas Negeri Jakarta , sekiranya dari hasil penelitian ini dapat dijadikan sebagai bahan untuk menyusun program latihan.

4. Penelitian ini dapat ditindak lanjuti dengan penelitian lain yang mengkaji variabel-variabel yang berhubungan dengan ketepatan memukul bola bisbol atau hal-hal yang penting guna menunjang prestasi pemain bisbol, dengan melakukan penelitian yang melibatkan variabel dalam jumlah yang lebih banyak, yang secara teoritik maupun empiris menunjang prestasi pemain bisbol.

\section{DAFTAR PUSTAKA}

Abdulkadir Ateng. 1992. Asas dan Landasan Pendidikan Jasmani. Jakarta: Departemen Pendidikan dan Kebudayaan Direktorat Jenderal Pendidikan Tinggi Proyek Pembinaan Tenaga Kependidikan.

Bethel, Dell. 1987. Petunjuk Lengkap Softball dan Baseball. terjemahan, Semarang: Dahara Prize.

Bompa, Tudor O. Teory and Methodology of Training; A Key to Athletic Performance. Dubuque, Iowa: Kendall/Hunt Publishing, 1994. 
Gallahue, David L. Understanding Motor Development Infants, Children, Adolescent. Indianapolis, Indiana: Bencmark Press, Inc., 1980.

Harrow. Anita J. A Taxonomy of the Psychomotor Domain A Guide for Developing Behavioral Objective. New York: Long man Inc., 1972.

Harsono. Coaching dan Aspek-aspek Psikologis dalam Coaching. Bandung: CV. Tombak Kususma, 1988.

Hiromi Saito, Morishigeyuki dan Saburi Takayuki. Softball "Teori dan Latihan". Jakarta: PB PERBASASI, 1997.

Kirkendall Don R., Gruber Joseph J and Johnson Robert E. Measurement and Evaluation for Physical Educations. Iowa: Brown Company Publisher, Inc., 1980.

Kneer Marian E. Softball Slow and Fast Pitch. Dubuque Iowa: Wm C. Brown Company Publisher, 1976.

Lamb. David R. Physical Education: An Interdiciplynary Approch. New York: The McMillan Company, 1972.

Lutan Rusli. Belajar Keterampilan Motorik, Pengantar Teori dan Metode. Jakarta: Departemen Pendidikan dan Kebudayaan, Ditjen Dikti, 1988.

Magill Richard A. Motor Learning: Concepts and Application. Dubuque Iowa: Wm C. Brown Company Publisher, 1985.

Sajoto M. Peningkatan dan Pembinaan Kekuatan Kondisi Fisik Dalam Olahraga. Semarang: Dahar price, 1996.

Schmidt, Richard A. Motor Control and Learning: A Behavioral Emphasis. Illinois: human Kinetics Publisher Inc, 1988.

Sudjana. Metode Statika. Bandung: Tarsito, 1992.

Sugianto dan Sudjarwo. Perkembangan dan Belajar Gerak. Jakarta: Depdikbud Proyek Penataran Guru Pendidikan Jasmani SD Setara DII, 1991.

Sullivan Geoge. Teknik Bermain Baseball, alih bahasa Hadinata. Bandung: Pioner Jaya, 1986.

Tetelepta Julius. Pedoman Permainan Baseball. Jakarta: FPOK IKIP Jakarta, 1994. 